\title{
Underemployment in the Turkish Labor Market ${ }^{1}$
}

\author{
Zehra Bilgen SUSANLI, Department of Economics, Isik University, Turkey; e-mail: \\ bilgen.susanli@isikun.edu.tr
}

\section{Türkiye İşgücü Piyasasında Eksik İstihdam²}

\begin{abstract}
Using individual-level data from Household Labor Force Surveys for the period 2009-2015, this paper examines the determinants of underemployment in the sample of wage and salary earners in Turkey. Findings from Probit estimations indicate that the effect of gender on the likelihood of underemployment is not statistically significant, and there is a negative association between educational attainment and the likelihood of underemployment. Within the group of higher educated individuals, there are important differences across fields of study.

Keywords : Underemployment, Turkey, Graduates.

JEL Classification Codes : I21, I23, J24.

\section{Öz}

Bu çalışmada 2009-2015 dönemine ait Hanehalkı İşgücü Anketleri mikro verileri kullanılarak ücretli ve maaşlı çalışanlar için eksik istihdamın belirleyicileri araştırılmıştır. Probit modeli tahminleri eğitim düzeyi ile eksik istihdamda olma ihtimali arasında ters yönlü bir ilişki olduğunu ve cinsiyetin eksik istihdamda olma ihtimali üzerindeki etkisinin istatistiki olarak anlamlı olmadığını göstermektedir. Üniversite ve üzeri eğitime sahip bireyler arasında mezun olunan bölüme göre önemli farklılıklar saptanmıştır.

Anahtar Sözcükler $\quad$ : $\quad$ Eksik İstihdam, Türkiye, Üniversite Mezunları.

1 This article is the revised and extended version of the paper presented in "Second International Annual Meeting of Sosyoekonomi Society" which was held by Sosyoekonomi Society and CMEE - Center for Market Economics and Entrepreneurship of Hacettepe University, in Amsterdam/The Netherlands, on October 28-29, 2016.

2 Bu makale Sosyoekonomi Derneği ile Hacettepe Üniversitesi Piyasa Ekonomisini ve Girişimciliği Gelişstirme Merkezi tarafindan Hollanda'nın Amsterdam şehrinde, 28-29 Ekim 2016 tarihlerinde düzenlenen "İkinci Uluslararası Sosyoekonomi Derneği Ylllık Buluşması"nda sunulan çalışmanın gözden geçirilmiş ve genişletilmiş halidir.
\end{abstract}




\section{Introduction}

It is well-documented that gross enrollment ratios in higher education are on the rise in the developing world (Yamada, 2015: 2-3; Yamada \& Lavado \& Martinez, 2015: 11-12). Despite the increase in the supply of university graduates, in many countries, employers report that they face obstacles to finding skilled workers. According to a survey conducted by McKinsey consultancy in 2012 in a sample of nine countries including Turkey, 43 percent of the employers report that lack of skills is a problem for filling entry-level vacancies; and only 50 percent of the surveyed youth believe that getting post-secondary education improved their employment opportunities ${ }^{3}$. These shares are 56 percent for the employers and 46 percent for the youth in the Turkish sample. The share of 25-34-year-olds holding a university diploma more than tripled from 8.8 percent to 27.5 percent between 2000 and 2015 in Turkey (OECD, 2016) ${ }^{4}$. Together with the persistently high unemployment rates of university graduates, this is indicative of significant mismatches between the skills gained during university education and those required by employers in the labor market.

There has been a growing emphasis on the labor market outcomes of the youth in the aftermath of the global financial crisis of 2008-2009. Much of the emphasis was on unemployment and inactivity, as unprecedented shares of the youth became either jobless or withdrew from the labor force. Although underemployment has received much less attention than unemployment, it is an important signal of the actual labor slack in the economy. Underemployment is also considered as hidden unemployment as it takes the form of subsistence agriculture, and irregular or casual employment in the informal sector in economies characterized by a lack of effective social safety net (Rutkowski, 2006: 20).

Underemployment is a multidimensional and complex construct. As such, it has been studied by researchers from various disciplines such as economics, management, sociology, and psychology ${ }^{5}$. Despite the multiplicity of definitions, all studies share the common aspect of underemployment reflecting a substandard job by some standard. This paper adopts the definitions of underemployment with regard to hours worked and inadequacy. According to the guidelines adopted at the $16^{\text {th }}$ International Conference of Labour Statisticians in 1998, there are two forms of underemployment. Time-related underemployment refers to situations when persons employed in the reference week work less than a threshold number of hours in total, and are willing to work for more hours, and available to do so. Employed individuals not covered under time-related underemployment are taken to be in inadequate

3 The survey report can be found at <http://mckinseyonsociety.com/downloads/reports/Education/Education-toEmployment_FINAL.pdf>.

4 The rise in the university graduates is an outcome of increases in both the demand for and supply of higher education. The number of higher education institutions (including state and non-profit foundation universities) rose from 70 in 2003 to 176 in 2014. For an analysis of the determinants of school choice at the secondary and tertiary level for the period of 1988-98 see Tunali (2003).

5 See McKee-Ryan and Harvey (2011) for a comprehensive review that builds on the work of Feldman (1996). 
employment if they report that they looked for a job in the last four weeks and that they are available to start working if a job is found. This definition of underemployment includes employed individuals that are willing to switch jobs for reasons that constrain their capacities and well-being, and are available to do so (ILO, 1998).

Using individual-level data from the Household Labor Force Surveys for the 20092015 period, this paper aims to investigate the determinants of the likelihood of being underemployed for the wage and salary earners in Turkey. Considering the different labor market behavior of men and women, separate analyses are conducted for men and women. Findings indicate that underemployment is negatively associated with educational attainment and firm size. Results also show that there is a roughly inverse-U relationship between age and the likelihood of being underemployed. Among the higher educated, underemployment is far less likely for some majors such as veterinary, health, and social and behavioral sciences relative to the base category of agriculture, forestry and fishery.

The rest of this paper is organized as follows. Section 2 provides a brief review of the related literature. Section 3 describes the data set and the empirical methodology. Section 4 presents the findings, and Section 5 discusses the policy implications and avenues for future research.

\section{Related Research}

There is an extensive literature on the adverse effects of underemployment on earnings and well-being in developed countries. Angrave and Charlwood (2015) find that a mismatch between desired and actual working hours lowers well-being in the UK. Bell and Blanchflower (2013) document a negative link between underemployment and life satisfaction for the UK. Wilkins (2007) and Wooden, Warren and Drago (2009) find similar results for Australia. Wunder and Heineck (2013) investigate the detrimental effects of working time mismatches on well-being in Germany and find that the negative impact of underemployment is stronger than that of overemployment. Findings in the work of Wunder and Heineck (2013) also indicate that there are spillovers from the partner's working time mismatch, in the sense that one's well-being is lower if his or her partner is underemployed.

Underemployment in the Turkish labor market is much less studied. Using data from Turkish Household Labor Force Surveys for the years 2000 and 2001, Taşçı (2006) examines the determinants of underemployment and finds that there is a negative relationship between education and the likelihood of being underemployed. Findings are also indicative of an inverse- $U$ relationship between age and underemployment. Using more recent data for the period 2006-2008, Taşçı and Darıcı (2010: 291-292) find that age, gender, marital status, and education are important factors. Their findings show that women and married individuals are significantly more likely to be underemployed. Consistent with the results in the paper by Taşçı (2006), their results are suggestive of an inverse-U relationship between age and the probability of underemployment. Kumaş and Çağlar (2011) study the determinants of underemployment in Turkey using data from 2009 Household Labor Force Survey. By separately estimating the likelihood of time related and inadequate 
underemployment, the authors find that individuals aged 15-24 and those with higher levels of education are more likely to be in time related and inadequate underemployment.

This paper is also related with a strand of literature that focuses on the underemployment of university graduates - the so-called "graduate underemployment". The underemployment of the graduates received much attention from researchers and the media as it became more widespread in developed countries after the global financial crisis (Abel \& Deitz, 2016; Chevalier \& Lindley, 2009; Green \& Zhu, 2010). Several papers study this concept under the topic of overeducation which occurs when an individual possesses a higher level of education or more qualifications than is required to do his or her job. Overeducation may be viewed as one of the potential sources of underemployment (Yamada, 2015). Theoretically, overeducation can be explained by several frameworks ${ }^{6}$. According to Search Models, overeducation may be an outcome of incomplete information and be of limited duration (Mortensen, 1986). Career Mobility Theory (Sicherman \& Galor, 1990) postulates that highly educated workers accept jobs for which they are overeducated with the aim of accumulating of human capital through experience and training. Accordingly, this model predicts a higher probability of promotion for the overeducated individuals. Therefore, overeducation is viewed as a temporary stage for accumulating human capital as younger workers use these jobs as stepping stones to better ones. The Job Competition Theory (Thurow, 1975) provides an explanation for overeducation by modeling a labor market characterized by workers competing for jobs. In this model, workers queue for jobs, and a worker's place in the queue depends on his or her relative training costs. A higher educated worker requires less training. Therefore, there is an incentive for a worker to overinvest in education to be ahead of other workers in the queue for a job. The Signaling Theory (Spence, 1973) considers a labor market characterized by imperfect information, and hence views education as a signal of ability. In this framework, education serves as a screening device for the employers. Consequently, workers aim to increase their chances of employment by acquiring more of the signal. If the educational requirements of the jobs remain constant, this leads to a rise in the educational attainment of the labor force relative what the jobs require.

In contrast with the stepping stone hypothesis of the Career Mobility Theory, a number of empirical studies find that overeducation is a persistent phenomenon (Baert \& Cockx \& Verhaest, 2012 for Belgium; Clark \& Joubert \& Maurel, 2014 for the US; Mosca \& Wright, 2011 for the UK). Also, some studies document that overeducation is associated with wage penalties and lower job satisfaction. Battu, Belfield, \& Sloane (2000) find that overeducation has negative effects on earnings and job satisfaction and that these effects are stronger for women. Caroleo and Pastore (2013) identify wage penalties associated with overeducation for university graduates in Italy. They also examine the determinants of overeducation and conclude that socioeconomic background and the field of study are 
important factors. Most arts and social sciences degrees are found to be associated with an educational mismatch. Green and Henseke (2016) measure underemployment using an index of graduate jobs, and their results confirm that underemployment is associated with lower job satisfaction and earnings in the sample of 21 countries. Findings in the work of Green and Henseke (2016) also show that the incidence of graduate underemployment is related with aggregate supply-demand imbalance rather than skills matching inefficiencies such as labor market flexibility.

Recently, there has been a shift from overeducation to skills mismatches. Empirical work in this line of research is based on the view that measures of overeducation may not reflect fully the extent to which a worker's skills are being utilized. Despite excess qualifications, some workers may lack some of the skills relevant to the job. Accordingly, Green and McIntosh (2007) consider two theories of overqualification. The first one is mismatch whereby workers do not find the jobs that are most suitable for their skills. In this view, the mismatch is an outcome of imperfect information or labor market rigidities. The second theory is based on worker heterogeneity whereby workers with the same qualifications differ with respect to skill levels. Findings in the work of Green and McIntosh (2007) suggest that for the UK, both theories are valid in particular situations. Their findings indicate that overqualification (under-qualification) reduces (increases) earnings relative to individuals with the same observable characteristics that are in jobs suitable to their qualifications. Along similar lines, Green and Zhu (2010) distinguish between overqualification and underutilization of skills and attribute the rising dispersion in the returns to university education in the UK to the increase in overqualification. Also, by distinguishing between skill mismatches and overqualification, Budría and Moro-Egido (2014) identify wage penalties for both groups in a sample of male workers from 12 European countries.

\section{Data and Empirical Methodology}

This paper uses individual-level data from Turkish Household Labor Force Surveys (HLFS) collected by Turk Stat (TÜİK) for the period 2009-2015 (TÜİK, 2009, 2010, 2011, 2012, 2013, 2014, and 2015). These surveys are cross-sections with a rotating panel component and are designed to be nationally representative. Each year about 150,000 households participate in the survey. The sample period for this study is taken to start with 2009 when the survey questionnaire was revised to provide accurate measures of underemployment. Along with information on age, gender, marital status, and educational attainment, the survey collects information on employment status, and the labor market history of the employed; and unemployment duration and job search methods of the unemployed. Of particular interest for this study is the question of hours worked by the employed individuals on the main job and the additional job, if any. The questionnaire also asks employed individuals if they have used any search channels to find another job in the last four weeks; and if they are willing to start in two weeks if a new job is found. The answers to these questions identify the individuals in time-related underemployment. According to TÜIK, employed individuals who worked less than 40 hours in total (in main job and additional job/s) in the reference week and who were willing to work additional 
hours and were available to do so are in time-related underemployment. Employed individuals not covered under time-related underemployment are identified as inadequately employed if they report having searched for a job in the last four weeks, and they are available to start working if a job is found. This definition of underemployment takes into account the mismatches between jobs and workers for reasons other than hours workers are willing to supply?

The HLFS questionnaire also collects information on the fields of study for the technical high school graduates and higher educated individuals. The fields of study are available in 21 categories. The survey questionnaire groups the individuals with a two or three-year degree from higher education institutions together with those holding an undergraduate or a graduate degree. The sample is restricted to wage and salary employed individuals that are aged between 15 and 64 years. Those that are attending school at the time of the survey are excluded from the sample to avoid confusion whether an individual's labor market behavior is affected by his or her schooling decision. This yields a working sample of 613,111 observations with a complete set of covariates.

A person is considered as underemployed if $\mathrm{s} / \mathrm{he}$ is in either time-related underemployment or inadequate employment. The share of underemployed in total employment gives the rate of underemployment. Figure 1 presents the trends in underemployment of men and women in the sample of all employed and of only the wage and salary employed. In addition to those in wage and salary employment, total employment consists of individuals that are employers, self-employed and unpaid family workers. Figure 1 shows that underemployment is much less prevalent among the wage and salary earners than in other employment states. The underemployment rates of men and women fell across both groups. While the underemployment rate of men declined from 5.4 percent in 2009 to 4.2 percent in 2015 , that of women dropped from 4.2 percent to 3.2 percent over the same period. Among the wage and salary employed, the underemployment rates of men and women exhibit similar patterns. As of 2015, the underemployment rates of wage and salary employed men and women stand at about 1.5 percent.

7 The analytical framework, concepts, and definitions regarding the labor force statistics produced by TÜIK can be reached at <http://www.turkstat.gov.tr/PreTablo.do?alt_id=1007>. 


\section{Figure: 1}

Trends in Underemployment, by gender (2009-2015)

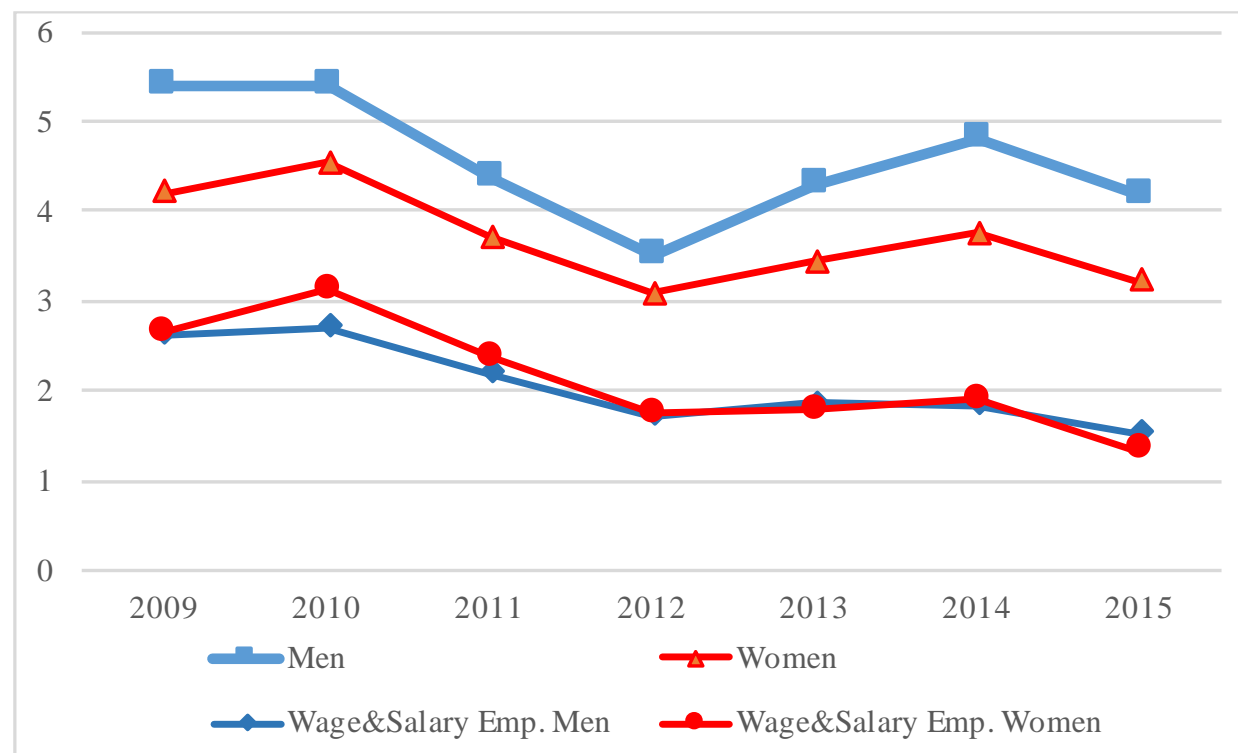

Source: Author's calculation using HLFS.

Figure 2 displays the rate of underemployment among the wage and salary earners by education over the sample period. As expected, underemployment falls with educational attainment. Underemployment rates have declined across all education categories over the sample years. The sharpest decline is observed among those with no education and those with 5-years primary school education. The underemployment rate among the higher educated fell from 1.6 percent in 2009 to 1.1 percent in 2015. As of 2015, the highest and the lowest rates of underemployment are found among individuals with no education (2.9 percent) and those with a vocational or technical high school degree ( 0.8 percent), respectively. 


\section{Figure: 2}

\section{Underemployment by Education}

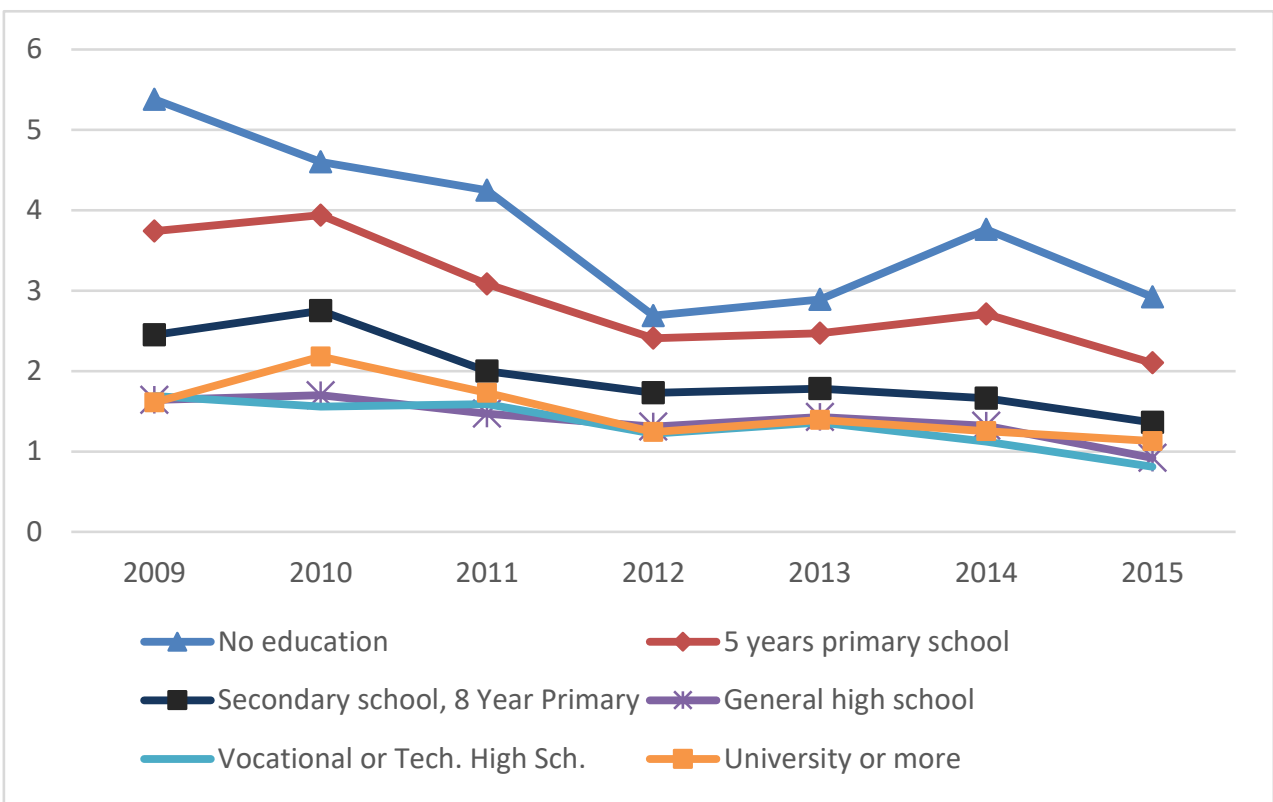

Source: Author's calculation using HLFS.

Table 1 shows the composition of employment and underemployment among the wage and salary earners with respect to gender, age, and education. Women constitute about 25 percent of both the employed and the underemployed. While the largest groups among the employed are those aged 30-34 and 35-39, the smallest groups are those aged 55-59 and 60-64. The age composition of the underemployed is similar. Underemployed individuals appear to be less educated, on average, than the employed. About 51.5 percent of the employed have less than high school education, and this is about 66.5 percent among the underemployed. While primary school graduates are overrepresented in underemployment (43.3 percent), those with a high school or higher education have disproportionately lower shares in underemployment. The table reveals some interesting patterns by gender. The employed women, on average, tend to be younger and better educated than employed men. While about 28.3 percent of employed men are younger than 30 years old, this is 33.5 percent for women. About 21 percent of employed men have a degree from a higher education institution, and this is 28 percent for women. While about 15 percent of underemployed men have a degree from a higher education institution, this share is 39 percent among the underemployed women. This may be a sign of the difficulties higher educated women face in finding jobs that match their education or skills in the labor market. 
Table: 1

The Composition of Total Employed and Underemployed by Age, Gender, and Education

\begin{tabular}{|c|c|c|c|c|c|c|}
\hline \multirow[b]{2}{*}{ Gender } & \multirow[t]{2}{*}{ Employed } & \multirow[t]{2}{*}{ Underemployed } & \multicolumn{2}{|c|}{ Employed } & \multicolumn{2}{|c|}{ Underemployed } \\
\hline & & & Men & Women & Men & Women \\
\hline Women & 24.7 & 24.9 & & & & \\
\hline \multicolumn{7}{|l|}{ Age } \\
\hline 15-19 & 4.8 & 4.1 & 4.8 & 4.7 & 4.2 & 3.7 \\
\hline $20-24$ & 9.3 & 9.3 & 8.4 & 12.0 & 8.7 & 11.1 \\
\hline $25-29$ & 15.5 & 15.8 & 15.1 & 16.8 & 16.1 & 14.8 \\
\hline $30-34$ & 17.4 & 17.9 & 17.1 & 18.1 & 17.9 & 18.1 \\
\hline $35-39$ & 16.3 & 17.0 & 16.1 & 16.9 & 16.5 & 18.4 \\
\hline $40-44$ & 14.6 & 14.1 & 14.6 & 14.6 & 13.5 & 16.1 \\
\hline $45-49$ & 11.4 & 10.7 & 12.1 & 9.5 & 10.7 & 10.5 \\
\hline $50-54$ & 6.5 & 6.4 & 7.0 & 4.7 & 7.0 & 4.5 \\
\hline $55-59$ & 3.1 & 3.7 & 3.5 & 1.9 & 4.1 & 2.3 \\
\hline $60-64$ & 1.2 & 1.1 & 1.3 & 0.7 & 1.3 & 0.5 \\
\hline \multicolumn{7}{|l|}{ Education } \\
\hline No education & 4.0 & 7.3 & 3.5 & 8.6 & 6.8 & 5.7 \\
\hline 5 years primary school & 30.6 & 43.3 & 32.4 & 41.8 & 43.8 & 24.8 \\
\hline Secondary school, 8 years education & 16.9 & 15.9 & 19.2 & 9.2 & 18.1 & 9.9 \\
\hline General high school & 11.0 & 7.5 & 11.2 & 7.0 & 7.7 & 10.6 \\
\hline Vocational or technical high school & 12.2 & 7.9 & 13.0 & 5.1 & 8.8 & 9.8 \\
\hline Higher education & 25.3 & 18.1 & 20.7 & 28.2 & 14.8 & 39.3 \\
\hline
\end{tabular}

Source: Author's calculation using HLFS.

Table 2 displays the composition of the employed and the underemployed among the higher educated individuals by their fields of study. The largest three groups among the employed are business and administration, teacher training and education sciences, and engineering and engineering trades with shares 23.3 percent, 19.9 percent, and 9.3 percent, respectively. Within the underemployed, the share of business and administration graduates is 12.5 percent; and that of teacher training and education sciences graduates is 43.7 percent. Also noteworthy is that humanities majors are overrepresented in the pool of underemployed. While only 5.9 percent of employed individuals are humanities majors, they constitute about 11.2 percent of the underemployed. The fact that graduates of teacher training and education sciences and humanities fields are substantially overrepresented in underemployment may be an indication of mismatches between demand and supply in the labor market. 
Table: 2

Fields of Study of the Employed and Underemployed

\begin{tabular}{lcc}
\hline & Total of employed & Underemployed \\
\hline Agriculture, forestry, and fishery & 2.7 & 1.7 \\
Architecture and building & 3.3 & 1.9 \\
Arts & 2.2 & 3.5 \\
Business and administration & 23.3 & 12.5 \\
Computing & 1.3 & 1.1 \\
Engineering and engineering trades & 9.3 & 5.9 \\
Health & 8.0 & 1.7 \\
Humanities & 5.9 & 11.2 \\
Journalism and information & 0.3 & 0.2 \\
Law & 1.3 & 0.1 \\
Life science & 1.3 & 1.7 \\
Manufacturing and processing & 1.8 & 1.5 \\
Mathematics and statistics & 1.6 & 3.2 \\
Personal services & 2.1 & 1.7 \\
Physical science & 3.0 & 3.2 \\
Security services & 3.0 & 0.2 \\
Social and behavioural sciences & 8.0 & 4.5 \\
Social services & 0.3 & 0.2 \\
Teacher training and education sciences & 19.9 & 43.7 \\
Transport services and environmental protectiol & 0.3 & 0.2 \\
Veterinary & 1.2 & 0.3 \\
\hline Total (\%) & 100 & 100 \\
Source: Author's calculation using HLFS. & &
\end{tabular}

Following Taş̧ı and Darıcı (2010), the probability of being underemployed will be estimated using the following Probit model with a latent variable $y^{*}$ that represents the propensity of being underemployed for individual i:

$$
\begin{aligned}
& y_{i}^{*}=x_{i}^{\prime} \beta+\varepsilon_{i}, \varepsilon_{i} \sim N(0,1), \\
& y_{i}=1 \text { if } y_{i}^{*}>0, \text { and } y_{i}=0 \text { if } y_{i}^{*} \leq 0
\end{aligned}
$$

where $y_{i}$ is the binary outcome variable; and $\mathrm{x}_{\mathrm{i}}$ is a vector of covariates that are expected to influence the likelihood of underemployment such as age, gender, marital status, education, 
and firm size. The age variable is available in 5-year brackets. To control for gender, a dummy variable that equals one if an individual is female is controlled for. Marital status is controlled for using a dummy variable that takes on the value one for married individuals, and zero otherwise. The education variable is a categorical variable that captures the highest level of education attained. Firm size is also a categorical variable that represents firms with number of employees equal to 10 or fewer, between 11 and 19, 20 and 49, and 50 or more. The field of study is also included in the estimation for the higher educated sample. To control for differences in the urban and rural labor markets, a binary variable will be used in separate estimations using the sample between $2009-2012^{8}$.

The binary outcome variable $\mathrm{y}_{\mathrm{i}}$ equals one if individual $i$ is observed in underemployment and zero otherwise. Assuming that the error term $\varepsilon_{i}$ is independent of $x$ and follows the standard normal distribution, the probability of underemployment is given by $\operatorname{Pr}\left(y_{i}=1 \mid x\right)=\Phi\left(x_{i}^{\prime} \beta\right)$ where $\Phi($.$) is the standard normal cumulative distribution.$

As is well known, the coefficients of the Probit model are not readily interpretable as the impact of right-hand side variables on the probability of the outcome variable as they belong to the latent model. The impact of a continuous control variable, $x_{k}$, on the probability of $\operatorname{Pr}\left(y_{i}=1 \mid x_{i}=x\right)$ is given by the following formula:

$$
\frac{\partial \operatorname{Pr}\left(y_{i}=1 \mid x\right)}{\partial x_{k}}=\beta_{k} \varphi\left(x_{i}^{\prime} \beta\right)
$$

where $\varphi($.$) is the standard normal density.$

The marginal effects depend on the values of the control variables at which they are evaluated. Therefore, this paper will report the average marginal effects. The average marginal effect of $\mathrm{x}_{\mathrm{k}}, A M E_{k}$, is calculated as follows:

$$
A M E_{k}=\frac{\partial \operatorname{Pr}\left(y_{i}=1 \mid x_{i}\right)}{\partial x_{i k}}=\frac{1}{n} \sum_{i=1}^{n} \beta_{k} \varphi\left(x_{i}^{\prime} \beta\right)
$$

where the summation is over the $\mathrm{n}$ individuals in the sample. For a dummy variable, the marginal effect is the difference between the two probabilities evaluated at the two values of the dummy variable. For a dummy variable, the average marginal effect is as follows:

8 According to TÜIK's classifications, urban areas are the settlements with a population greater than or equal to 20,000. One noteworthy point about the dataset is that in 2013, with Law No. 6360 a number of administrative division changes were introduced in the town, district, and province classifications in Turkey. Accordingly, as of 2013, information on the location of households at the urban-rural breakdown is no longer included in the HLFS micro datasets although urban-rural residence is still used in the stratification of the sample. 


$$
A M E_{k}=\frac{1}{n} \sum_{i=1}^{n}\left[\Phi\left(x_{i}^{\prime} \beta \mid x_{i k}=1\right)-\Phi\left(x_{i}^{\prime} \beta \mid x_{i k}=0\right)\right]
$$

Separate analyses will be made for men and women on the basis that the labor market behavior of men and women are likely to be quite distinct.

\section{Main Findings}

Table 3 presents the average marginal effects from estimating the set of equations using maximum likelihood. Column (1) shows the results for the total sample controlling for age, gender, marital status, education, and firm size. The region of residence at the NUTS2 level and year dummies are also controlled for. Consistent with the inverse-U shaped effect of age found in the papers by Taşçı (2006) and Taş̧̧ı and Darıcı (2010), the magnitude of the average marginal effects of the age variables initially rise and then decline after the age of 40-44. The average marginal effect of the female dummy is not statistically significant. Results also show that the likelihood of underemployment falls with educational attainment. Individuals with vocational or technical high school education are, on average, 1.3 percentage points less likely to be underemployed relative to those with no education. Findings also indicate that individuals that work in larger firms are less likely to be underemployed relative those working in firms with 10 or fewer employees. Column (2) presents the results from controlling for the urban-rural residence of individuals. This estimation is based on the observations coming from the survey years between 2009 and 2012. Contrary to the results in the work of Taşçı (2006) and Taşçı and Darıcı (2010), the average marginal effect of the urban dummy is negative indicating a negative association between living in an urban area and the likelihood of being underemployed. This discrepancy may be an artifact of the differences in the composition of the samples. The sample used in Taşçı and Darıcı (2010) includes individuals across all employment statuses and as shown in the previous section, the underemployment rates of wage and salary earners are lower than those in other employment states. The average marginal effects of the other variables except gender remain largely the same as in Column (1). Columns (3) and (4) present the average marginal effects from the Probit estimations separately for women and men, respectively. While the results are qualitatively the similar across the two samples, the average marginal effects of education and firm size seem to be stronger for men than for women. As for the impact of age, women aged 60-64 years are on average 1 percentage point less likely to be underemployed relative to those aged 15-19 years. 
Table: 3

Determinants of Underemployment

\begin{tabular}{|c|c|c|c|c|c|c|c|c|}
\hline \multirow[b]{2}{*}{ Age (Omitted $=15-19)$} & \multicolumn{2}{|l|}{ All sample } & \multicolumn{2}{|c|}{ All sample } & \multicolumn{2}{|l|}{ Women } & \multicolumn{2}{|l|}{ Men } \\
\hline & Avg. Marginal Effect & S.e. & $\begin{array}{c}\text { Marginal } \\
\text { Effect }\end{array}$ & S.e. & $\begin{array}{c}\text { Avg. Marginal } \\
\text { Effect }\end{array}$ & S.e. & $\begin{array}{c}\text { Avg. Marginal } \\
\text { Effect }\end{array}$ & S.e. \\
\hline $20-24$ & $0.009^{* *}$ & $(0.001)$ & $0.010 * *$ & $(0.001)$ & $0.008 * *$ & $(0.002)$ & $0.009 * *$ & $(0.001)$ \\
\hline $25-29$ & $0.011 * *$ & $(0.001)$ & $0.012 * *$ & $(0.001)$ & $0.007 * *$ & $(0.002)$ & $0.012 * *$ & $(0.001)$ \\
\hline $30-34$ & $0.011 * *$ & $(0.001)$ & $0.012 * *$ & $(0.001)$ & $0.008 * *$ & $(0.002)$ & $0.012 * *$ & $(0.001)$ \\
\hline $35-39$ & $0.011 * *$ & $(0.001)$ & $0.011 * *$ & $(0.001)$ & $0.008 * *$ & $(0.002)$ & $0.011 * *$ & $(0.001)$ \\
\hline $40-44$ & $0.009 * *$ & $(0.001)$ & $0.009 * *$ & $(0.001)$ & $0.008 * *$ & $(0.002)$ & $0.009 * *$ & $(0.001)$ \\
\hline $45-49$ & $0.007 * *$ & $(0.001)$ & $0.007 * *$ & $(0.001)$ & $0.007 * *$ & $(0.002)$ & $0.007 * *$ & $(0.001)$ \\
\hline $50-54$ & $0.007 * *$ & $(0.001)$ & $0.007 * *$ & $(0.002)$ & 0.003 & $(0.003)$ & $0.009 * *$ & $(0.001)$ \\
\hline $55-59$ & $0.009 * *$ & $(0.001)$ & $0.010 * *$ & $(0.002)$ & $0.005+$ & $(0.003)$ & $0.010 * *$ & $(0.002)$ \\
\hline 60-64 & 0.002 & $(0.002)$ & 0.002 & $(0.003)$ & $-0.010+$ & $(0.005)$ & $0.005^{*}$ & $(0.002)$ \\
\hline Female & 0.000 & $(0.000)$ & $0.001 *$ & $(0.001)$ & & & & \\
\hline Married & $-0.001 *$ & $(0.001)$ & -0.001 & $(0.001)$ & $-0.002+$ & $(0.001)$ & -0.001 & $(0.001)$ \\
\hline \multicolumn{9}{|l|}{ Education (Omitted $=$ No education) } \\
\hline 5 years primary school & $-0.003 * *$ & $(0.001)$ & $-0.004 * *$ & $(0.001)$ & 0.002 & $(0.001)$ & $-0.006 * *$ & $(0.001)$ \\
\hline Secondary school, 8 years edu. & $-0.009 * *$ & $(0.001)$ & $-0.010 * *$ & $(0.001)$ & $-0.007 * *$ & $(0.002)$ & $-0.011 * *$ & $(0.001)$ \\
\hline General high school & $-0.014 * *$ & $(0.001)$ & $-0.015 * *$ & $(0.001)$ & $-0.013 * *$ & $(0.002)$ & $-0.015 * *$ & $(0.001)$ \\
\hline Vocational or technical high sch. & $-0.013 * *$ & $(0.001)$ & $-0.014 * *$ & $(0.001)$ & $-0.016 * *$ & $(0.002)$ & $-0.013 * *$ & $(0.001)$ \\
\hline University or more & $-0.008 * *$ & $(0.001)$ & $-0.009 * *$ & $(0.001)$ & $-0.006 * *$ & $(0.002)$ & $-0.009 * *$ & $(0.001)$ \\
\hline \multicolumn{9}{|l|}{ Firm size (Omitted $=10$ or fewer) } \\
\hline $11-19$ & $-0.012 * *$ & $(0.001)$ & $-0.012 * *$ & $(0.001)$ & $-0.008 * *$ & $(0.001)$ & $-0.013 * *$ & $(0.001)$ \\
\hline $20-49$ & $-0.018 * *$ & $(0.001)$ & $-0.019 * *$ & $(0.001)$ & $-0.015 * *$ & $(0.001)$ & $-0.019 * *$ & $(0.001)$ \\
\hline 50 or more & $-0.027 * *$ & $(0.001)$ & $-0.028 * *$ & $(0.001)$ & $-0.024 * *$ & $(0.001)$ & $-0.027 * *$ & $(0.001)$ \\
\hline Urban & & & $-0.001 *$ & $(0.001)$ & & & & \\
\hline $\mathrm{N}$ & 613111 & & 432901 & & 151233 & & 461878 & \\
\hline Chi sq & 12652.741 & & 10243.050 & & 3401.563 & & 9529.983 & \\
\hline$P$ value & 0.000 & & 0.000 & & 0.000 & & 0.000 & \\
\hline Pseudo R squared & 0.103 & & 0.111 & & 0.111 & & 0.103 & \\
\hline Log likelihood & -55181.215 & & -41022.253 & & -13564.926 & & -41476.758 & \\
\hline
\end{tabular}

Note: Author's calculations using HLFS 2009-2015. Average marginal effects from Probit estimation are presented. Robust standard errors in parentheses. Also controlled for are year fixed effects and NUTS2 dummies.,$+ *$, and $* *$ denote $10 \%, 5 \%$, and $1 \%$ levels of significance, respectively. 
Table 4 displays the average marginal effects controlling for the field of study in higher education.

Table: 4

Determinants of Underemployment of the Higher Educated

\begin{tabular}{|c|c|c|c|c|c|}
\hline & Avg. & & & Avg. Margin & \\
\hline & Marginal & S.e. & & Effect & S.e. \\
\hline Age $($ Omitted $=15-19)$ & & & & & \\
\hline $20-24$ & 0.000 & $(0.011)$ & Business and administration & $-0.018^{* *}$ & $(0.001)$ \\
\hline $25-29$ & -0.002 & $(0.010)$ & Computing & -0.010 & $(0.006)$ \\
\hline $30-34$ & -0.004 & $(0.011)$ & Engineering and engineering trades & $-0.020 * *$ & $(0.001)$ \\
\hline 35-39 & -0.004 & $(0.011)$ & Health & $-0.040^{* *}$ & $(0.007)$ \\
\hline $40-44$ & -0.006 & $(0.011)$ & Humanities & $-0.006^{* * *}$ & $(0.002)$ \\
\hline $45-49$ & -0.006 & $(0.011)$ & Journalism and information & $-0.009^{* * *}$ & $(0.002)$ \\
\hline $50-54$ & -0.005 & $(0.011)$ & Law & -0.002 & $(0.002)$ \\
\hline $55-59$ & -0.005 & $(0.011)$ & Life science & $-0.016^{* *}$ & $(0.003)$ \\
\hline $60-64$ & -0.010 & $(0.011)$ & Manufacturing and processing & $-0.016^{* *}$ & $(0.001)$ \\
\hline Female & $-0.002 * *$ & $(0.001)$ & Mathematics and statistics & $-0.014^{* *}$ & $(0.002)$ \\
\hline Married & $-0.006 * *$ & $(0.001)$ & Personal services & $-0.019^{* * *}$ & $(0.002)$ \\
\hline Firm size (Omitted $=10$ or fewer $)$ & & & Physical science & $-0.021^{* *} *$ & $(0.002)$ \\
\hline $11-19$ & $-0.004 * *$ & $(0.001)$ & Security services & $-0.027 * *$ & $(0.005)$ \\
\hline $20-49$ & $-0.006^{* * *}$ & $(0.001)$ & Social and behavioural sciences & $-0.029 * *$ & $(0.002)$ \\
\hline 50 or more & $-0.008^{* *}$ & $(0.001)$ & Social services & $-0.013^{*}$ & $(0.006)$ \\
\hline Area of study (Omitted: Agri., forestry, and & & & & & \\
\hline fishery) & & & Teacher training \& education sciences & $-0.017^{* *} *$ & $(0.002)$ \\
\hline Architecture and building & $-0.003+$ & $(0.002)$ & Transport services \& env.protection & $-0.018^{* *}$ & $(0.007)$ \\
\hline Arts & $-0.002+$ & $(0.001)$ & Veterinary & $-0.044 * *$ & $(0.005)$ \\
\hline $\mathrm{N}$ & & 155081 & & & \\
\hline Chi sq & & 3306.343 & & & \\
\hline$P$ value & & 0.000 & & & \\
\hline Pseudo R squared & & 0.139 & & & \\
\hline Log likelihood & & -10268.892 & & & \\
\hline
\end{tabular}

Note: Author's calculations using HLFS 2009-2015. Average marginal effects from Probit estimation are presented. Robust standard errors in parentheses. Also controlled for are year fixed effects and NUTS2 dummies. +, *, and ** denote $10 \%, 5 \%$, and $1 \%$ levels of significance, respectively.

The average marginal effects of the age groups are not statistically significant. Women and married people are significantly less likely to be underemployed. Although the average marginal effects of the gender and married dummies are statistically significant, their magnitudes are rather small ( 0.2 and 0.6 percentage points, respectively). Examination of the average marginal effects of the fields of the study reveals that relative to the base category of agriculture, forestry and fishery fields, individuals with degrees from all other fields are significantly less likely to be underemployed. The fields of study with the largest marginal effects are veterinary, health and social and behavioral sciences.

\section{Conclusion}

This paper investigates the determinants of underemployment for the wage and salary employed individuals in Turkey. Findings indicate that there is a negative association between education and the likelihood of underemployment, and this is stronger for men. In 
contrast with expectations, gender is not a significant factor in explaining the likelihood of underemployment. Individuals working in larger firms are less likely to be underemployed.

Analyses also provide interesting insights into the determinants of underemployment among the higher educated individuals by taking into account their fields of study. First, findings imply that age is not a significant factor in explaining the likelihood of underemployment. Second, among the higher educated individuals, women and married individuals are significantly less likely to be underemployed although the magnitude of this effect is small. Third, relative to the agriculture, forestry and fishery majors, individuals with veterinary, health, and social and behavioral science degrees are significantly less likely to be underemployed.

The detrimental effects of underemployment on earnings and life satisfaction are well-documented in the literature. These topics have been underexplored in Turkey, and therefore constitute important avenues for future research. Considering the effort and resources allocated to the preparations for university admissions process in Turkey, the relationship between the fields of study in higher education and subsequent labor market outcomes is certainly worth further investigation.

\section{References}

Abel, J.R. \& R. Deitz (2016), "Underemployment in the Early Careers of College Graduates Following the Great Recession", NBER Working Paper, 22654, National Bureau of Economic Research, Cambridge, Mass.

Angrave, D. \& A. Charlwood (2015), "What is the Relationship between Long Working Hours, Over-employment, Under-employment and the Subjective Well-being of Workers? Longitudinal Evidence from the UK”, Human Relations, 68(9), 1491-1515; doi:10.1177/0018726714559752

Baert, S. \& B. Cockx \& D. Verhaest (2012), "Overeducation at the Start of the Career: Stepping Stone or Trap?”, IZA Discussion Paper, 6562, IZA, Bonn.

Battu, H. \& C.R. Belfield \& P. Sloane (2000), "How Well Can We Measure Graduate OverEducation and Its Effects?", National Institute Economic Review, 171(1), 82-93.

Bell, D.N.F. \& D.G. Blanchflower (2013), “How to Measure Underemployment?”, Peterson Institute for International Economics Working Paper, 13/2, Washington, DC.

Buchel, F. (2001), “Overqualification: Reasons, Measurement Issues and Typological Affinity to Unemployment", in: Training in Europe, P. Descy \& M. Tessaring (eds.), Second report on vocational training research in Europe 2000: background report, (Cedefop Reference series), Luxembourg: Office for Official Publications of the European Communities, 2001 (3 volumes); ISBN 92-896-0034-0

Budría, S. \& A. Moro-Egido (2014), "Overqualification, Skill Mismatches and Wages in Private Sector Employment in Europe", Technological and Economic Development of Economy, 20(3), 457-83.

Caroleo, F.E. \& F. Pastore (2013), "Overeducation at a Glance: Determinants and Wage Effects of the Educational Mismatch: Looking at the AlmaLaurea Data", IZA Discussion Paper, 7788, IZA, Bonn. 
Chevalier, A. \& J. Lindley (2009), “Over-Education and the Skills of UK Graduates”, Journal of the Royal Statistical Society: Series A (Statistics in Society), 172, 307-337; doi:10.1111/j.1467-985X.2008.00578.x

Clark, B. \& C. Jaubert \& A. Maurel (2014), "The Career Prospects of Overeducated Americans", NBER Working Paper, 20167, National Bureau of Economic Research, Cambridge, Mass.

Dooley Prause, D.J. \& K.A. Ham-Rowbottom (2000), "Underemployment and Depression: Longitudinal Relationships", Journal of Health and Social Behavior, 41(4), 421-36, $<$ https://webfi les.uci.edu/psbstaff /1-25-10\%20ColloquiumSE\%20Perspectives\%20on\%20Psych\%20Research/Depression.pdf>, 25.01.2016.

Feldman, D.C. (1996), “The Nature, Antecedents and Consequences of Underemployment”, Journal of Management, 22(3), 385-407.

Green, F. \& G. Henseke (2016), "Should Governments of OECD Countries Worry about Graduate Underemployment?”, Oxford Review of Economic Policy, 32(4), 517-37.

Green, F. \& S. McIntosh (2007), "Is There a Genuine Under-utilization of Skills amongst the OverQualified?", Applied Economics, 39(4), 427-39.

Green, F. \& Y. Zhu (2010), "Overqualification, Job Dissatisfaction, and Increasing Dispersion in the Returns to Graduate Education", Oxford Economic Papers, 62, 740-63.

International Labour Organization (1998), Report of the Sixteenth Conference of Labour Statisticians, Geneva: ILO.

Kumaş, H. \& A. Çağlar (2011), "Türkiye'de Kadın Eksik İstihdamını Belirleyen Faktörler: TÜİK 2009 Hanehalkı İşgücü Anketi Ham Verileri ile Cinsiyete Dayalı bir Karşılaştırma”, Çalışma ve Toplum, 2, 249-289.

McKee-Ryan, F.M. \& J. Harvey (2001), ““I Have a Job But ...” A Review of Underemployment”, Journal of Management, 37(4), 962-96.

Mortensen, D.T. (1986), "Job Search and Labor Market Analysis”, in: Handbook of Labor Economics, O. Ashenfelter \& R. Layard (eds.) Amsterdam: North Holland, 849-920.

Mosca, I. \& R.E. Wright (2011), "Is Graduate Under-employment Persistent? Evidence from the United Kingdom”, IZA Discussion Paper, 6177, IZA, Bonn.

OECD (2016), Population with tertiary education (indicator), doi:10.1787/0b8f90e9-en, 13.12.2016.

Rutkowski, J. (2006), "Labor Market Developments during Economic Transition”, World Bank Policy Research Working Paper, 3894, World Bank, Washington, DC.

Sicherman, N. \& O. Galor (1990), “A Theory of Career Mobility”, Journal of Political Economy, 98(1), 168-92.

Spence, M. (1973), “Job Market Signaling”, The Quarterly Journal of Economics, 87(3), 355-74.

Taşçı, H.M. (2006), "Recent Trends in Underemployment and Determinants of Underemployment in Turkey”, Süleyman Demirel Üniversitesi İktisadi ve İdari Bilimler Fakültesi Dergisi, 11(1), 299-319.

Taşçı, H.M. \& B. Darıcı (2010), “Türkiye'de Eksik İstihdamın Belirleyenleri: HIA ile Bir Mikro Veri Uygulamas1", Maliye Dergisi, 158, 279-300.

Thurow, L.C. (1975), Generating Inequality, Basic Books, New York.

Türkiye İstatistik Kurumu (2009), Hanehalkı İsgücü Araştırması Mikro Veri Seti 2009, Ankara.

Türkiye İstatistik Kurumu (2010), Hanehalkı İsgücü Araştırması Mikro Veri Seti 2010, Ankara. 
Türkiye İstatistik Kurumu (2011), Hanehalkı İsgücü Araştırması Mikro Veri Seti 2011, Ankara. Türkiye İstatistik Kurumu (2012), Hanehalkı Iş̧ü̈ü Araştırması Mikro Veri Seti 2012, Ankara. Türkiye İstatistik Kurumu (2013), Hanehalkı İsgücü Araştırması Mikro Veri Seti 2013, Ankara. Türkiye İstatistik Kurumu (2014), Hanehalkı İşü̈cü Araştırması Mikro Veri Seti 2014, Ankara. Türkiye İstatistik Kurumu (2015), Hanehalkı İsgücü Araştırması Mikro Veri Seti 2015, Ankara. Tunali, I. (2003), "General vs. Vocational Secondary School Choice and Labor Market Outcomes in Turkey, 1988-98", Paper presented at the 10th annual ERF conference in Morocco, December, 2003.

Wilkins, R. (2007), "The Consequences of Underemployment for the Underemployed", Journal of Industrial Relations, 49(2), 247-275.

Wooden, M. \& D. Warren \& R. Drago (2009), "Working Time Mismatch and Subjective Wellbeing", British Journal of Industrial Relations, 47(1), 147-179.

Wunder, C. \& G. Heineck (2013), "Working Time Preferences, Hours Mismatch and Well-being of Couples: Are There Spillovers?", Labour Economics, 24, 244-52.

Yamada, G. (2015), "The Boom in University Graduates and the Risk of Underemployment", IZA World of Labor, 166, doi:10.15185/izawol.166

Yamada, G. \& P. Lavado \& J.J. Martinez (2015), “An Unfulfilled Promise? Higher Education Quality and Professional Underemployment in Peru”, IZA Discussion Paper, 9591, IZA, Bonn. 
Susanl, Z.B. (2017), "Underemployment in the Turkish Labor Market”, Sosyoekonomi, Vol. 25(33), 157-173. 